\title{
ZASTOSOWANIE NIESTANDARDOWEGO KRYTERIUM OPTYMALIZACJI W TRANSFORMACJI HELMERTA PRZY PRZELICZANIU WSPÓLRZĘDNYCH
}

\begin{abstract}
Podczas wykonywania transformacji zdarzaja się sytuacje, gdy niektóre współrzędne punktów dostosowania wykazują cechy obserwacji odstających. Konsekwencją wykorzystania takich punktów do wyznaczenia parametrów transformacji, są następnie zbyt duże wartości poprawek do współrzędnych punktów łącznych. Eliminacja punktów, których poprawki przekraczają dopuszczalne wartości w pewnych przypadkach może całkowicie uniemożliwić wykonanie zadania. Rozwiązaniem tego typu problemu może być implementacja kryterium minimalizacji sumy czwartych potęg przesunięć współrzędnych punktów dostosowania $\mathrm{w}$ procesie transformacji. W proponowanej metodzie uzyskuje się mniejszą niż w przypadku kryterium najmniejszych kwadratów odchyłkę maksymalną na punktach dostosowania. Własność ta może być szczególnie pożądana $\mathrm{w}$ przypadku, gdy mamy do czynienia $\mathrm{z}$ małą liczbą punktów dostosowania. W artykule przedstawiono podstawy teoretyczne metody, opisano technikę zapewnienia zbieżności procesu iteracyjnego oraz przedstawiono wyniki przeprowadzonych testów.
\end{abstract}

Słowa kluczowe: transformacja współrzędnych, punkty łączne, metoda sumy czwartych potęg, metoda najmniejszych kwadratów

\section{Wstęp}

Wykonując transformację współrzędnych pomiędzy dwoma układami zdarza się, że część współrzędnych punktów łącznych zawiera różnego rodzaju błędy, które pojawiły się np. w bazie danych z bliżej nie określonych powodów (czynności manualnych) lub w wyniku nowego pomiaru, w sytuacji gdy znak punktu został przemieszczony lub uszkodzony. Sposobem rozwiązania tego

${ }^{1}$ Autor do korespondencji: Joanna Janicka: Instytut Geodezji, Olsztyn ul. Oczapowskiego 1, 89 523-42-04, joannasuwm@gmail.com

2 Sławomir Cellmer: Instytut Geodezji, Olsztyn ul. Oczapowskiego 1, 89 523-42-04, slawomir.cellmer@gmail.com 
typu problemu jest zastosowanie odpornej na błędy grube estymacji. Wówczas w procesie wyznaczania parametrów transformacji wprowadza się dowolną funkcję wagową, której zadaniem jest zidentyfikowanie obserwacji odstających, a następnie poprzez odpowiednie wagowanie zmniejszenie ich wpływu na wyznaczane parametry transformacji. W literaturze występuje wiele różnych metod, które mogą być wykorzystane w tym celu, np. wszelkie metody zaliczane do grupy metod odpornej m-estymacji, czyli funkcja Hubera, Hampela, duńska, narastającego rygoru [8], ZWA [6] lub metoda M-split estymacji [9]. Największym ograniczeniem zastosowania wymienionych metod jest liczebność obserwacji odstających w stosunku do całego zbioru danych. Jeżeli obserwacji obarczonych błędami grubymi jest więcej niż 40-45\% wówczas skuteczność ich jest niewielka. Często powyżej progu 50\% następuje zamiana i algorytm prawidłowe obserwacje traktuje jako odstające. Metodą, która znacznie lepiej sprawdza się przy większej liczbie błędnych danych jest metoda RANSAC, opisana $\mathrm{w}$ pracy [2] i zastosowana $\mathrm{w}$ transformacji współrzędnych [3]. Kolejną ciekawą koncepcją rozwiązywania problemu transformacji współrzędnych jest zastosowanie niestandardowego kryterium optymalizacji - kryterium minimalizacji sumy czwartych potęg [1]. Jest to metoda, którą można zastosować w pewnych szczególnych przypadkach, gdy eliminacja punktów, których odchyłki przekraczają dopuszczalne wartości, całkowicie uniemożliwiłoby wykonanie zadania. Zaproponowana przez autorów publikacji metoda pozwala na uzyskanie wartości poprawek do tychże punktów o wartościach nieprzekraczających dopuszczalnych określonych w przepisach.

\section{Kryterium optymalizacji sumy czwartych potęg}

W klasycznym podejściu parametry transformacji estymowane są metodą najmniejszych kwadratów (NK). Estymacja wektora parametrów transformacji tą metodą polega na rozwiązaniu następującego problemu optymalizacyjnego:

$$
\left\{\begin{array}{c}
V=A X+L \\
C_{L}=\sigma_{0}^{2} Q_{L}=\frac{1}{\sigma_{0}^{2}} P^{-1} \\
\min \left\{\xi(X)=V^{T} P V\right]=\hat{V}^{T} P V
\end{array}\right.
$$

gdzie: $C_{L}$ - macierz kowariancji wektora wyrazów wolnych $\mathbf{L}$ (współrzędnych

w układzie wtórnym),

$Q_{L}$ - macierz kofaktorów,

$P=Q_{L}^{-1}$ - macierz wag,

$\sigma_{0}^{2}$ - współczynnik wariancji. 
Metoda najmniejszych kwadratów należy do klasy M-estymacji w ramach której, metody estymacji można opisać odpowiednimi funkcjami charakterystycznymi. Podstawą do zdefiniowania tych funkcji jest określenie zewnętrznej funkcji celu oraz jej składowych. Funkcje charakterystyczne definiowane są następująco:

- Funkcja wpływu

$$
\varphi(v)=\frac{\partial \rho(v)}{\partial v}
$$

- Funkcja rygoru

$$
u(v)=\frac{\partial^{2} \rho(v)}{\partial v^{2}}
$$

- Funkcja wagowa

$$
w(v)=\frac{\partial \rho(v)}{\partial\left(v^{2}\right)}
$$

Klasyfikację metod estymacji opartą na własnościach funkcji charakterystycznych przedstawił prof. R. Kadaj [5] . Zgodnie z tą klasyfikacją można wyodrębnić podklasy estymacji:

- estymację słabą,

- estymację neutralną,

- estymację mocną.

W przypadku wzajemnej niezależności wyrównywanych wielkości macierz wag $\mathbf{P}$ jest diagonalna. Wówczas funkcję celu $\xi(X)$ problemu optymalizacyjnego można zapisać w postaci:

$$
\xi(X)=\sum_{i=1}^{n} p_{i} v_{i}^{2}
$$
celu:

Zatem metodzie najmniejszych kwadratów odpowiada następująca funkcja

$$
\rho(v)=p v^{2},
$$

oraz funkcja wagowa

$$
w(v)=p,
$$

i funkcja rygoru

$$
u(v)=2 p
$$


Przedstawiona powyżej klasyfikacja opiera się głównie na własnościach funkcji wagowej odgrywającej szczególną rolę w analizie własności metod należących do M-estymacji. Na podstawie funkcji wagowej wyznaczane są elementy macierzy wag w kolejnych krokach iteracyjnych. Na rysunku 1 przedstawiono przebieg funkcji wagowej w zależności od typu estymacji.

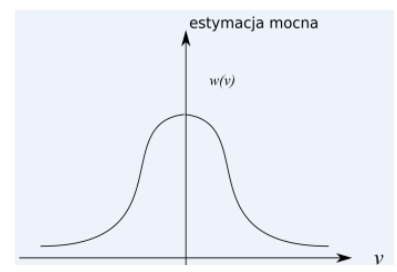

a)

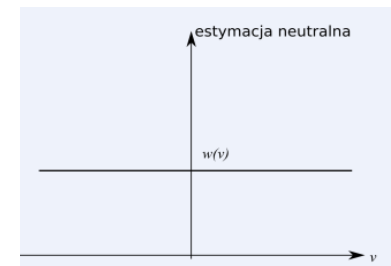

b)

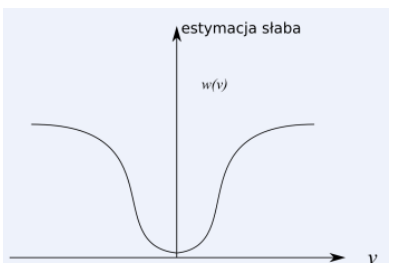

c)

Rys. 1 Funkcja wagowa dla trzech typów estymacji: a) mocna, b) neutralna, c) słaba

Fig. 1 Weight function for three types of estimation : a) robust, b) neutral, c) weak

Ponieważ w metodzie NK funkcja wagowa jest stała, więc zalicza się ją do metod neutralnych, czyli nieodpornych na błędy grube. Kryterium minimalizacji sumy czwartych potęg należy do zbioru estymacji określanej mianem słabej, ponieważ obserwacje odstające mają większy wpływ na rozwiązanie niż obserwacje mieszczące się w przedziale dopuszczalnym. Funkcja celu związana z funkcją wagową słabej estymacji może przyjmować postać sumy czwartych potęg:

$$
\rho_{i}(v)=v_{i}^{4}
$$

Kryterium optymalizacji zaproponowane w artykule i szczegółowo opisane w [1] można zapisać jako:

$$
\xi(X)=\sum_{i=1}^{n} v_{i}^{4}=\min
$$

Funkcję celu można przedstawić w zapisie macierzowym :

$$
\xi(X)=v_{2}^{T} v_{2}=\min \square
$$

gdzie:

$$
v_{2}=\left[v_{1}^{2} v_{2}^{2 n}{ }^{2}, v_{n}^{2}\right]
$$

Istnieje wiele technik poszukiwania minimum funkcji celu. Najbardziej popularną i wykorzystaną przez autorów jest metoda zerowania gradientu funkcji celu z zastosowaniem współczynnika k, szczegółowo opisana w pracy [1]. 


\section{Transformacja Helmerta $z$ zastosowaniem sumy czwartych potęg}

Transformację Helmerta $\mathrm{z}$ zastosowaniem metody minimalizacji sumy czwartych potęg zaproponowano $\mathrm{w}$ procesie przeliczania współrzędnych pomiędzy układami z kilku względów. Po pierwsze, zdarzają się sytuacje, gdy współrzędne punktów dostosowania wykazują cechy obserwacji odstających. Teoretycznie najlepszym rozwiązaniem byłoby wyeliminowanie takich punktów ze zbioru punktów łącznych. Jednakże praktyka pokazuje, że takie podejście może całkowicie uniemożliwić rozwiązanie zadania ponieważ liczba punktów łącznych będzie zbyt mała albo geometria rozmieszczenia punktów zostanie zniekształcona, co również może mieć wpływ na wynik transformacji.

Innym aspektem są wartości poprawek obliczanych do współrzędnych punktów łącznych. Zastosowanie metod odpornej M-estymacji w procesie wyznaczania parametrów transformacji zidentyfikuje punkt odstający, nada mu odpowiednią wagę, ale wartość odchyłki znacznie przekroczy dopuszczalną wartość określoną przepisami. W takich przypadkach metoda sumowania czwartych potęg może mieć zastosowanie.

Odchyłki (poprawki) oraz błąd transformacji są niezbędne do oceny poprawności współrzędnych punktów dostosowania. Błąd transformacji $\mathrm{m}_{\mathrm{t}}$ nie powinien przekraczać wielkości dopuszczalnego błędu położenia punktu $\mathrm{m}_{\mathrm{p}}$ w danej klasie sieci (np. dla punktów II klasy państwowej błąd nie może być większy niż $0,05 \mathrm{~m}$ ) pod warunkiem, że współrzędne punktów dostosowania nie są obarczone błędami systematycznymi lub grubymi. Wielkości odchyłek współrzędnych na punktach dostosowania nie mogą wynosić więcej niż wartość $\mathrm{k} \cdot \mathrm{m}_{\mathrm{p}}$, gdzie $\mathrm{k}$ przyjmuje wartości między 2 i 3 , co zależy od liczby punktów dostosowania lub od szczególnych ograniczeń ujętych w warunkach technicznych roboty [7].

Zatem w przypadku, gdy w zbiorze punktów dostosowania znajdują się punkty, których współrzędne obarczone są błędami możliwe są następujące rozwiązania:

- wyeliminowanie takiego punktu, jeżeli wiadomo który to punkt (jeśli eliminacja punktu nie wpłynie na poprawne rozwiązanie),

- zastosowanie odpornej na błędy grube metody estymacji, która zminimalizuje wpływ błędu na wyznaczane parametry transformacji, ale wartości poprawek do współrzędnych punktów łącznych obarczonych błędem grubym mogą przekraczać dopuszczalne wartości,

lub

- zastosowanie metody sumowania czwartych potęg, która umożliwi pozostawienie punktu istotnego $\mathrm{z}$ punktu widzenia geometrii rozmieszczenia punktów łącznych, a wartość odchyłki zmieści się w ramach dopuszczalnych wartości. 


\section{Obliczenia}

Zaproponowaną $\mathrm{w}$ pracy metodę transformacji z zastosowaniem minimalizacji sumy czwartych potęg w dalszej części pracy autorzy nazywają „transformacją słabą" ze względu na przynależność do zbioru estymacji określanej mianem słabej. Transformację słabą przetestowano na obiekcie rzeczywistym. W celu przeprowadzenia testów porównawczych wskazujących na skuteczność przedstawionej metody wykorzystano autorski program, który realizuje standardową transformację Helmerta oraz transformację Helmerta z wykorzystaniem metody minimalizacji sumy czwartych potęg. Wykonano szereg obliczeń zgodnie z zaproponowanym algorytmem zmieniając wartości błędów grubych, którymi obarczano współrzędne punktów łącznych oraz ich liczbę. Aby zaprezentować wyniki przeprowadzonych badań wybrano trzy warianty: jeden bezbłędny oraz dwa z różnymi wartościami błędów którymi zaburzono współrzędne punktów dostosowania.

Badania przeprowadzono na fragmencie rzeczywistej sieci składającej się z 1144 punktów, spośród których 8 stanowi zbiór punktów dostosowania.

W I wariancie obliczeń przyjęto, że punkty dostosowania nie są obarczone błędami grubymi. Na rysunku 2 i 3 przedstawione są wartości poprawek do współrzędnych punktów łącznych otrzymane w wyniku estymacji metodą najmniejszych kwadratów oraz metodą sumy czwartych potęg wykorzystanej w tzw. transformacji słabej.

\section{Poprawki do współrzędnych X}

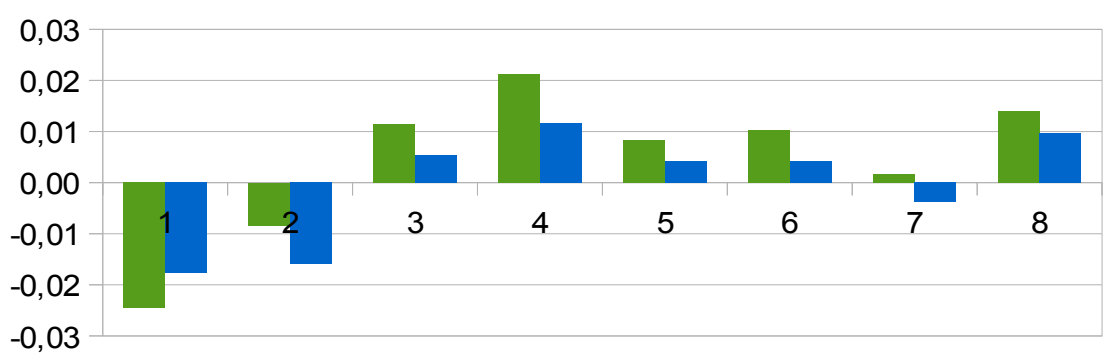

- Słaba transformacja Helmert

Rys. 2 Poprawki do współrzędnych X punktów łącznych - wariant bezbłędny

Fig. 2 Values of $\mathrm{X}$ residuals - scenario without outliers 
Poprawki do współrzędnych Y

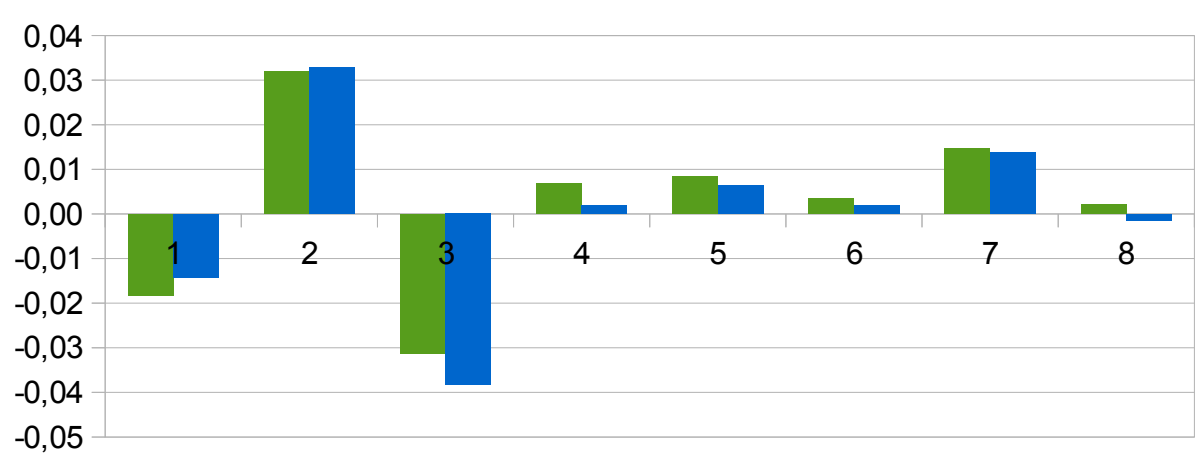

Słaba transformacja Helmert

Rys. 3 Poprawki do współrzędnych Y punktów łącznych - wariant bezbłędny

Fig. 3 Values of Y residuals - scenario without outliers

$\mathrm{Na}$ podstawie rysunków 2 i 3 można stwierdzić, że w sytuacji, gdy współrzędne punktów łącznych nie są obarczone żadnymi błędami grubymi wówczas obie metody pozwalają uzyskać podobne wyniki.

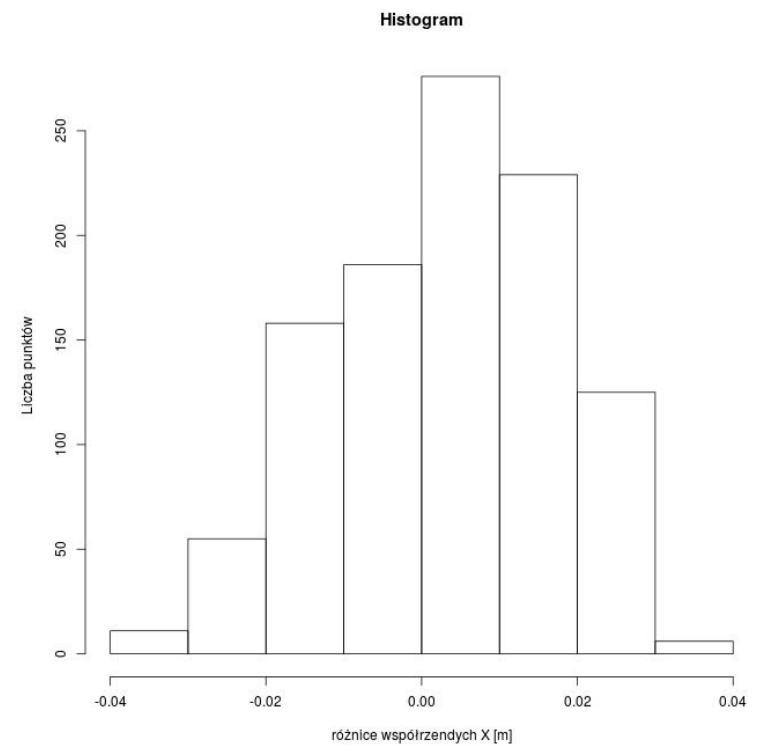

Rys.4 Histogram różnic współrzędnych X - transformacja Helmerta i słaba

Fig. 4 Histogram of coordinate differences $\mathrm{X}$ - Helmert transformation and weak transformation 
W Obu przypadkach wartości poprawek nie przekraczają $4 \mathrm{~cm}$. Po obliczeniu parametrów transformacji oraz wartości poprawek wykonano transformację współrzędnych pozostałych punktów oraz obliczono różnice pomiędzy wartościami otrzymanymi $\mathrm{z}$ przeliczenia a wartościami tzw. katalogowymi. Na rysunkach 4 i 5 przedstawiono histogramy obliczonych różnic współrzędnych. Ponieważ wyniki obliczeń były bardzo zbliżone, dlatego przedstawiono je na wspólnych histogramach.

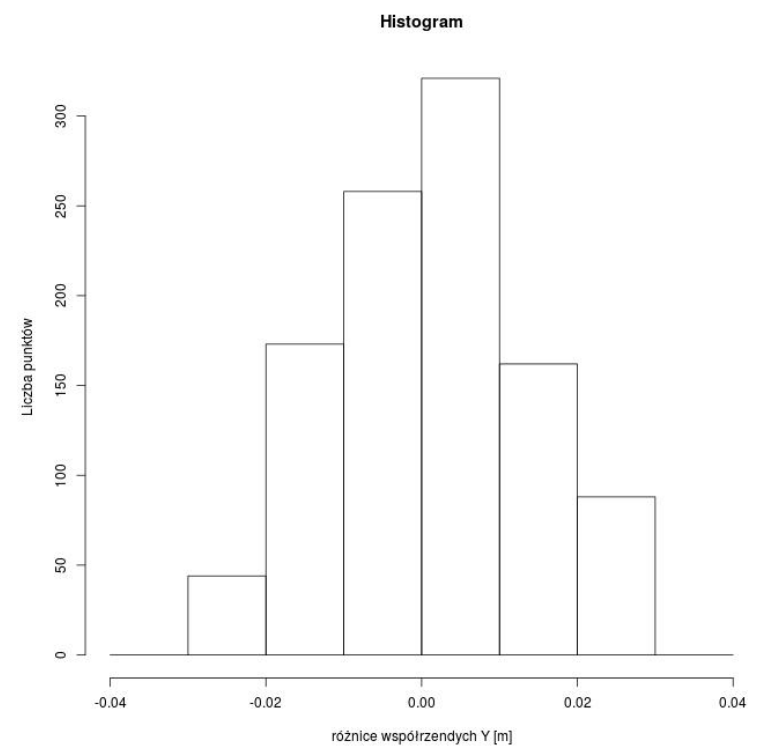

Rys. 5 Histogram różnic współrzędnych Y - transformacja Helmerta i słaba

Fig. 5 histogram of coordinate differences $\mathrm{Y}$ - Helmert transformation and weak transformation

Analizując wyniki obliczeń przedstawione na rysunkach 4 i 5 można stwierdzić, że w obu przypadkach różnice współrzędnych pomiędzy wartościami katalogowymi, a uzyskanymi z transformacji nie przekraczają $4 \mathrm{~cm}$.

Następny wariant obliczeniowy polegał na tym, że współrzędne wybranych punktów dostosowania obarczono błędami grubymi. Współrzędną Y punktu nr $1 \mathrm{w}$ układzie wtórnym zaburzono błędem o wartości $40 \mathrm{~cm}$ oraz współrzędną $\mathrm{X}$ punktu $\mathrm{nr} 2$ błędem $8 \mathrm{~cm}$. Na rysunkach 6 i 7 zaprezentowano wartości otrzymanych poprawek do współrzędnych punktów dostosowania. 


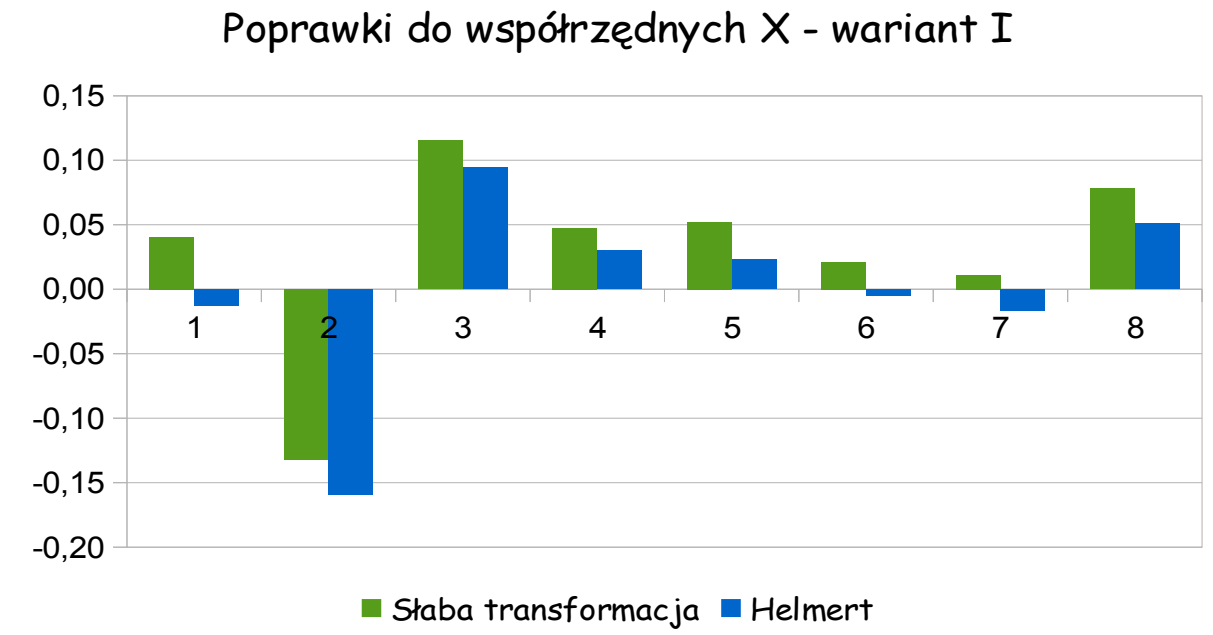

Rys. 6 Poprawki do współrzędnych X punktów łącznych - wariant I

Fig. 6 Values of $\mathrm{X}$ residuals - the first scenario

\section{Poprawki do wspótrzędnych Y - wariant I}

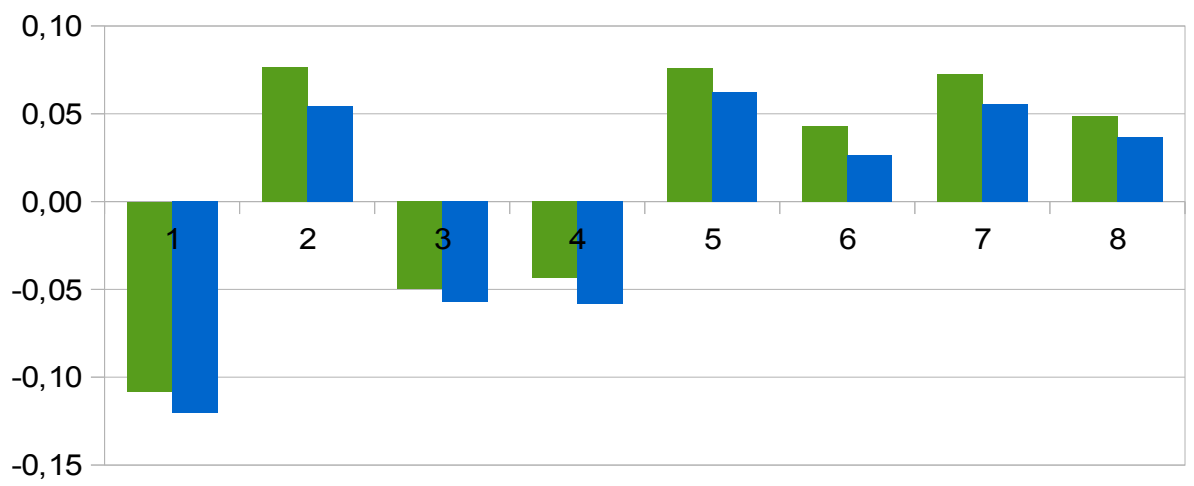

- Słaba transformacja Helmert

Rys. 7 Poprawki do współrzędnych Y punktów łącznych - wariant I

Fig. 7 Values of Y residuals - the first scenario

Przyjmując założenie, że dla punktów II klasy osnowy państwowej błąd nie może być większy niż 0,05 m wówczas wielkości odchyłek współrzędnych na punktach dostosowania nie powinny przekroczyć $15 \mathrm{~cm}$. W zaprezentowanym wyżej przykładzie, w sytuacji, gdy niektóre z punktów łącznych są obarczone błędem grubym wówczas tradycyjne rozwiązanie metodą najmniejszych kwadratów sugerowałoby odrzucenie punktu $\mathrm{nr} 2$ (rys.6) ponieważ wartość poprawki przekracza $15 \mathrm{~cm}$. Zastosowanie metody 
minimalizacji sumy czwartych potęg pozwala zachować ten punkt w zbiorze punktów łącznych, a wartość poprawki nie przekracza $15 \mathrm{~cm}$. Rysunek 8 prezentuje histogramy różnic współrzędnych X katalogowych i po transformacji słabej $\mathrm{z}$ zastosowaniem metody sumy czwartych potęg oraz transformacji Helmerta.

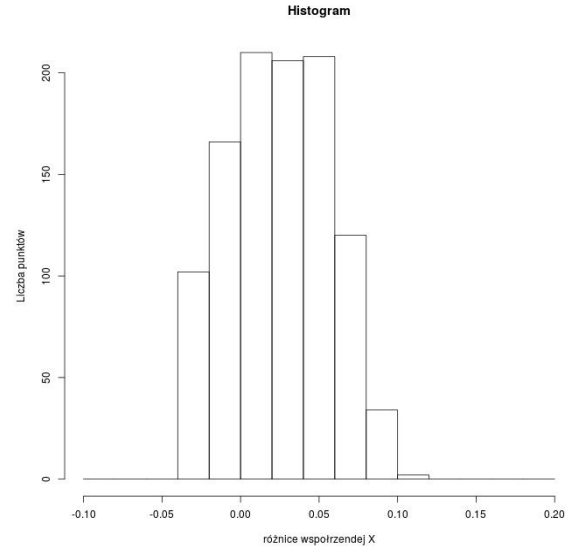

a) transformacja słaba

a) week transformation

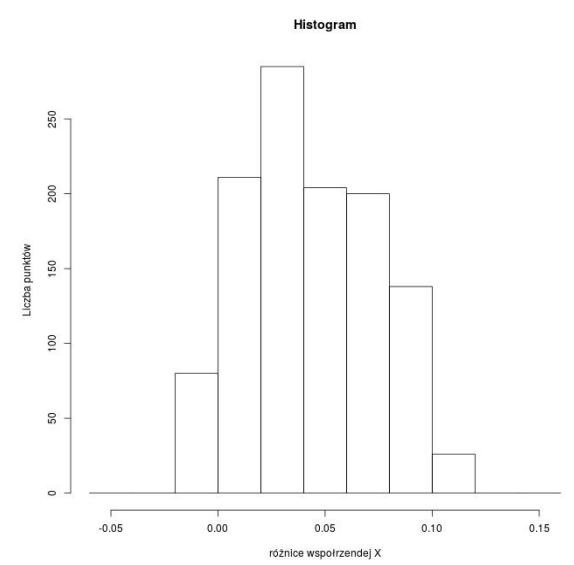

b) transformacja Helmerta

b) Helmert transformation

Rys. 8 Histogram różnic współrzędnych $\mathrm{X}$

Fig. 8 Histogram of coordinate differences $\mathrm{X}$

Rysunek 9 przedstawia histogramy różnic współrzędnych Y otrzymanych w wyniku obu transformacji.

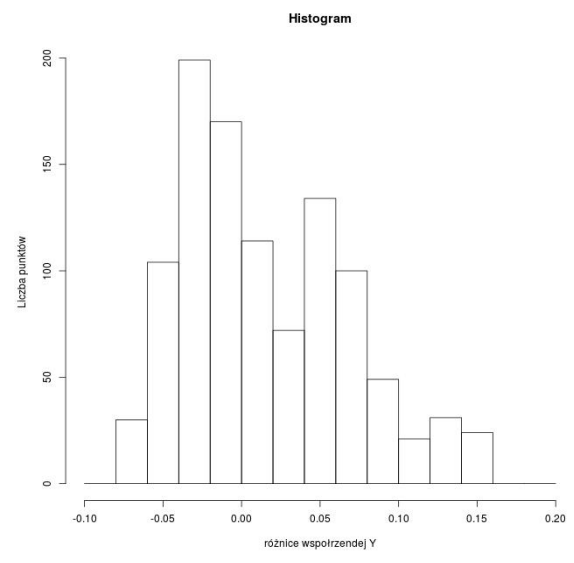

a) transformacja słaba

a) week transformation

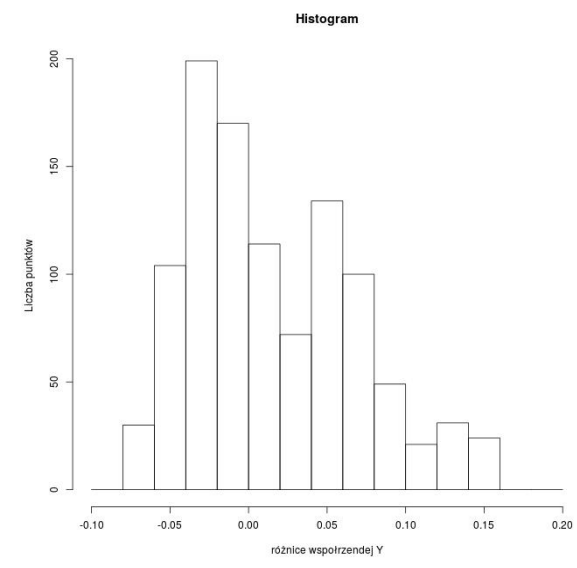

b) transformacja Helmerta b) Helmert transformation

Rys. 9 Histogram różnic współrzędnych Y

Fig.9 Histogram of coordinate $\mathrm{Y}$ differences 
$\mathrm{Na}$ podstawie wyników zaprezentowanych w postaci histogramów przedstawionych na rysunkach 8 i 9 można zaobserwować, że wyniki obu transformacji są podobne. Różnice współrzędnych X i Y dla obu metod osiągają podobne wartości.

Wariant drugi obliczeń to trzy współrzędne obarczone błędami grubymi o wartościach około $30 \mathrm{~cm}$. Błędami zaburzono współrzędne: Y1, X2 i Y8. Rysunki 10 i 11 prezentują otrzymane wyniki.

\section{Poprawki do współrzędnych X - wariant II}

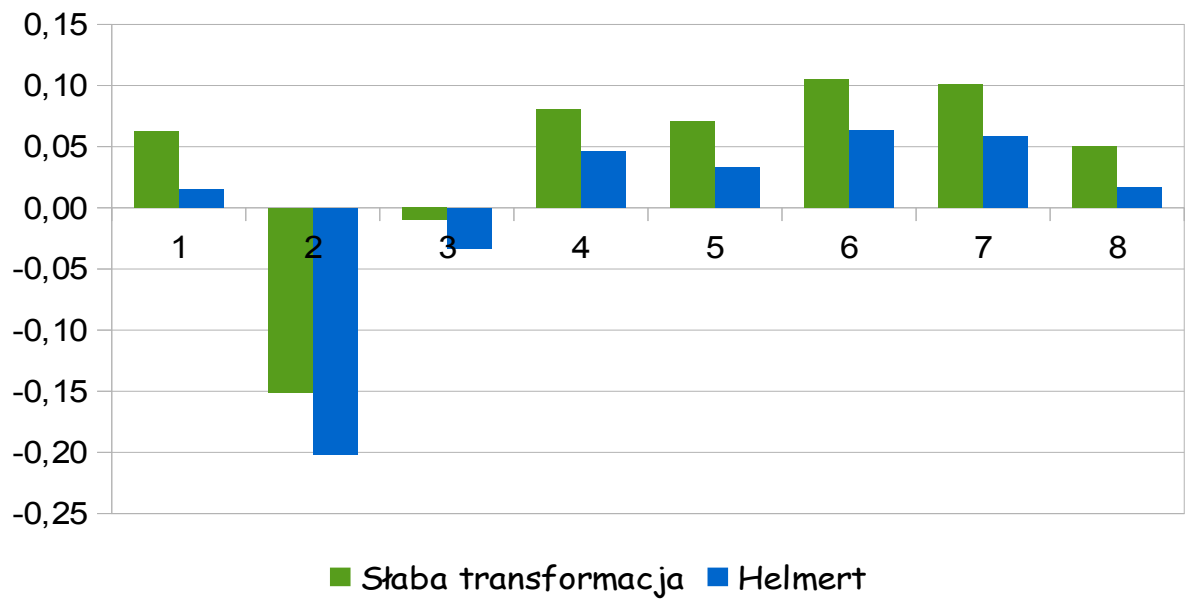

Rys.10 Poprawki do współrzędnych X punktów łącznych - wariant II

Fig. 10 Values of $\mathrm{X}$ residuals - the second scenario

Poprawki do wspótrzenych Y - wariant II

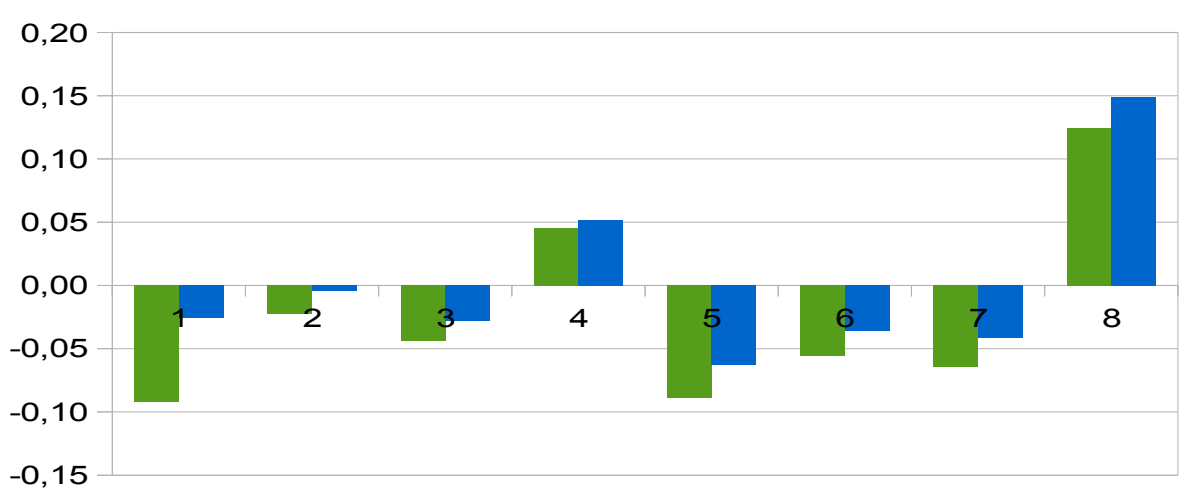

Słaba transformacja Helmert

Rys. 11 Poprawki do współrzędnych Y punktów łącznych - wariant II

Fig.11 Values of Y residuals - the second scenario 
$\mathrm{Na}$ podstawie zaprezentowanych wartości poprawek do współrzędnych punktów dostosowania ponownie można zaobserwować, że metoda minimalizacji sumy czwartych potęg zmniejszyła wartość największej poprawki do takiej wartości, która pozwala zachować ją, jako punkt łączny transformacji, ponieważ mieści się $\mathrm{W}$ przedziale dopuszczalnym. Podobnie jak przy poprzednich wariantach, przetransformowano pozostałe punkty do układu wtórnego i obliczono różnice współrzędnych. Wyniki w postaci histogramów przedstawiono na rysunkach 12 i 13 .

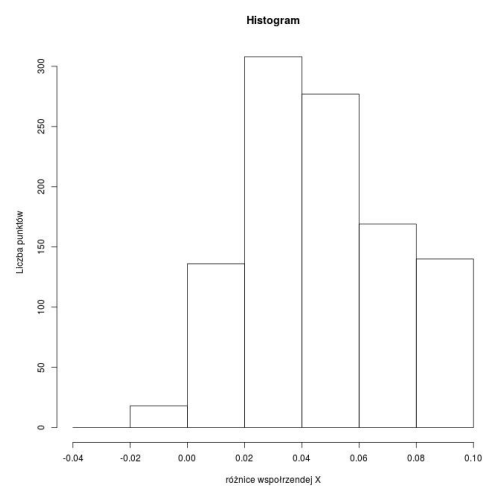

a) transformacja słaba a) week transformation

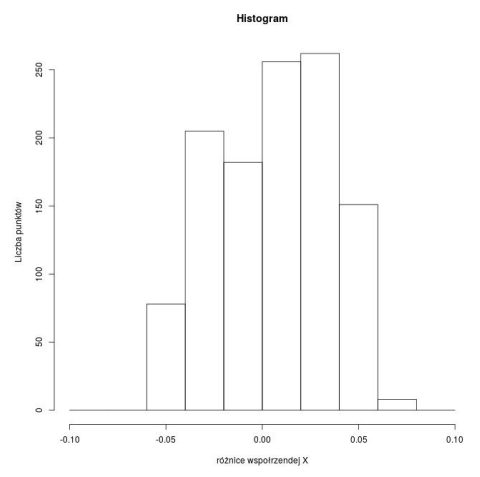

b) transformacja Helmerta b) Helmert transformation

Rys. 12 Histogram różnic współrzędnych X - transformacja słaba wariant II

Fig. 12 Histogram of coordinate $\mathrm{X}$ differences

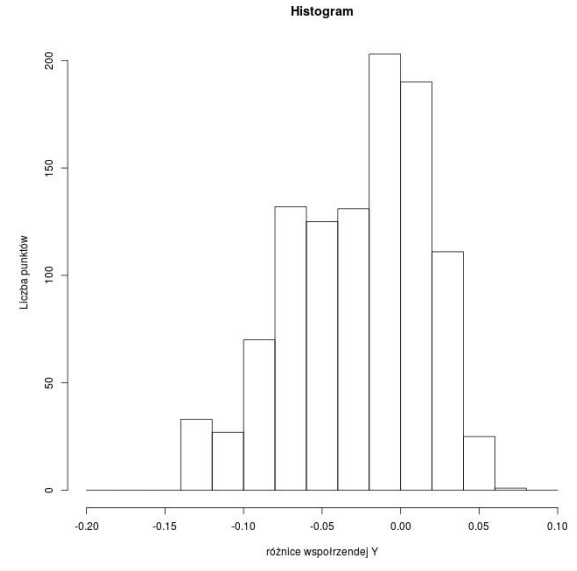

a) transformacja słaba a) week transformation

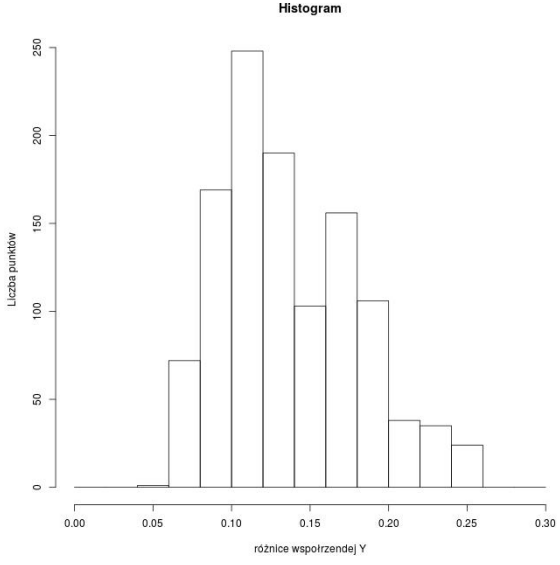

b) transformacja Helmerta

b) Helmert transformation

Rys.13 Histogram różnic współrzędnych Y - transformacja słaba wariant II

Fig. 13 Histogram of coordinate $Y$ differences 
Wyniki transformacji przedstawione na rysunkach 12 i 13 wskazują, że dzięki zastosowaniu metody sumy czwartych potęg otrzymano mniejsze różnice pomiędzy wartościami katalogowymi, a otrzymanymi w wyniku obliczeń. W przypadku transformacji słabej różnice osiągają maximum $13 \mathrm{~cm}$, natomiast $\mathrm{w}$ przypadku standardowej transformacji Helmerta wynoszą ponad $25 \mathrm{~cm}$.

\section{Podsumowanie}

Analizując przeprowadzone badania i uzyskane wyniki można stwierdzić, że zastosowanie metody sumy czwartych potęg w procesie wyznaczania parametrów transformacji oraz obliczania poprawek do współrzędnych punktów dostosowania pozwala otrzymać lepsze rezultaty niż przy standardowym rozwiązaniu. Istotną kwestią są wartości odchyłek na puntach dostosowania, które nie powinny przekraczać pewnych określonych wartości. W przypadku, gdy zastosowanie klasycznej metody najmniejszych kwadratów wskazywałoby na eliminację punktów, których odchyłki przekraczają maksymalne wartości zaproponowana „transformacja słaba” sprowadza te wartości do poziomu, w którym mieszczą się one w wielkościach dopuszczalnych. Jest to ważne, gdyż pozwala na zachowanie punktu dostosowania, co w pewnych przypadkach jest istotne dla geometrii rozkładu punktów łącznych.

\section{Literatura}

[1] Cellmer, S.: The Least Fourth Powers - an optimization method favoring outliers, Survey Review 2014, DOI http://dx.doi.org/10.1179/1752270614Y.0000000142.

[2] FISCHLER, M., BOLLES, R.: Random Sample Consensus: A Paradigm for Model Fitting with Applications to Image Analysis and Automated Cartography, Communications of the ACM. Vol 6 (24), 1982, pp. 381-395,

[3] Janicka J, Rapinski J.: Outliers detection by RANSAC algorithm in the transformation of 2D coordinate frames, The Bulletim of Geodetic Science Vol 20 , number 3, 2014.

[4] Janicka J, Rapinski J.: Modified RANSAC transformation of coordinates burdened with outliers . Environmental Engineering Vilnus, 2014,

[5] Kadaj R.: Eine verallgemeinerte Klasse von Schätzverfahren mit praktischen Anwendungen. Z Vermessungswesen 113(4), 1988, pp 157-166.

[6] Kadaj R.: Rozwinięcie koncepcji niestandardowej metody estymacji, Geodezja i Kartografia, 1979

[7] Kadaj R.2002. Polskie układy współrzędnych, formuły transformacyjne, algorytmy i programy. Rzeszów 2002r., www.geonet.net.pl.

[8] Kamiński, W., Wiśniewski Z.: Analiza wybranych, odpornych na błędy grube, metod wyrównania obserwacji geodezyjnych, Geodezja i Kartografia 1992.

[9] Wiśniewski, Z., Estimation of parameters in a split functional model of geodetic observations (Msplit estimation), Journal of Geodesy, Vol 83, 2008, pp. 105-120. 


\section{TRANSFORMATION OF COORDINATES WITH THE LEAST FOURTH POWERS METHOD}

During the coordinate transformation, there are situations that some coordinates of the reference points are burdened with outliers. The consequence of using such reference points, to determine the transformation parameters, are then too large values of residuals. The reference points burdened with outliers should be removed from the set of reference points, but sometimes this eliminations can completely prevents from completing the task. The solution to this type of problem can be the implementation of the criterion of the least fourth powers method in the process of coordinate transformation. The proposed method allows to receive less values of the residuals than the least squares method. This property may be particularly desirable especially in case of a small number of reference points. The paper presents the theoretical basis of the method, describes a technique to ensure the convergence of the iterative process and the results of tests.

Keywords: Helmert transformation, week transformation, the least fourth powers method

Przestano do redakcji:30.05.2015

Przyjęto do druku:10.01.2016

DOI: $10.7862 / \mathrm{rb} .2015 .186$ 